\title{
Debating Honor in Fifth- Century BCE Athens: Towards a Comparative and Intradisciplinary Approach
}

Andrea Giannotti

Durham University, Department of Classics \& Ancient History, 38 North Bailey, Durham, DH1 3EU, UK https://orcid.org/0000-0002-4893-0499

andrea.giannotti1990@gmail.com

\begin{abstract}
This article tries less to give a practical demonstration than to theoretically sketch out and propose a novel approach to a specific aspect of ancient Greek culture, namely $\tau u$ in (honor) and the pursuit of it. Its aim is not only to illustrate the potential proficiency of such a methodology (and to set the ground for its application), but also to highlight concrete opportunities in the Humanities to study how the language of civic institutions in epigraphic sources and the moral language of ethical philosophy penetrate poetry in Greece: the idea that inscriptions and ethical philosophy are something that scholars of poetry should leave to ancient historians and philosophers has left lots of room for new scholarship in this area. Special attention is devoted here to Euripidean drama and its characters who, in exhibiting specific virtues (e.g. benevolence, solidarity, and friendship) while establishing reciprocal relationships, stand as socio-ethical examples of the pursuit of an honorable status within one's community. Scholars have not fully explored to what extent this portrayal matches historical evidence for benefactions/exchanges between Greek citizens/cities and, at the same time, it complies with the virtues described by Aristotle's ethical works. By interpreting honor as a means by which people regulate their social lives, the objective of this article is to show how Euripidean drama can serve as a valuable source to be explored for understanding Greek moral attitudes.
\end{abstract}

Keywords: literature and ethics / ancient Greek drama / epigraphy / Euripides / Aristotle / moral philosophy / honor

In 1997 the journal Classical Philology published the 1994 APA's Panel Discussion entitled Classics and Comparative Literatures: Agenda for the '90s. Given the marginalization of Classics within the field of Humanities during the last decades of the twentieth century, the 
authors' simple aim was "to initiate a conversation about the relation of Classics to other humanistic disciplines and its role in the humanities in general" (Branham et al. 153). They sought not to demonstrate but to concretely apply Classics' ability to speak to classicists as well as to other scholars in the humanities and social sciences: interdisciplinary studies were (and still are) the key. Not being a scholar in Comparative Literature, I do not feel entitled to exhaustively illustrating how Classics can make use of Comparative Literature. However, I agree with the approach of Glenn Most's erudite paper in the abovementioned volume, and equally aim to discuss the "generous cosmopolitanism" between different disciplines as a possible solution to address (and hopefully one day solve) the dilemmas surrounding a specific Classical theme.

Friedrich Nietzsche stated that "what cannot be exhausted is the always new adjustment every age makes to the classical world, of measuring ourselves against it" (Arrowsmith 296). If this is the case, then, for my modest part I can say that my on-going research ideas aim to bring an adjustment to the Classical world by providing useful criteria of an intradisciplinary ${ }^{1}$ and comparative approach, which might achieve more results than a one-directional and specialized approach. For instance, the so-called "French School" established by Louis Gernet and Jean-Pierre Vernant provided a striking model by focusing on ancient society through a free anthropological approach in the name of interdisciplinarity and comparison. Indeed, if we are dealing with a plural subject, we are bound to deal with it by means of a plural examination. Hence, in the words of Giulia Sissa, interdisciplinary means that "what counts is not the comprehension of the thought of an author, but the meaning revealed by a passage juxtaposed with examples from other sources in order to demonstrate the consistency of a certain general idea which is attributed [...] to "the Greeks"' (in Branham et al. 168-169). Conversely, comparison is "an interpersonal confrontation among experts of different cultures" or fields. In accordance with these two parameters, I will focus here on the Greek concept of $\tau \mu$ í (generally translatable as "honor") to show how it can be productively analyzed through a similar approach, i.e. by juxtaposing

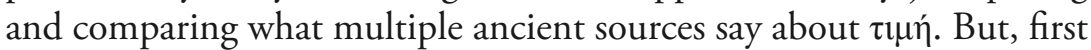
of all, why focus on $\tau \imath \mu$ ?

${ }^{1}$ I use the the word "intradisciplinary" rather than "interdisciplinary" as ancient Greek theatre, ancient Greek epigraphy, and ancient philosophy (specifically Aristotle) are three different disciplines sharing the same heading, namely Classics. 
In 1974, Kenneth J. Dover claimed that, in order to be able to reconstruct a lifelike picture of Greek norms of behavior we would need "hundreds of private diaries and account-books, parish records and thousands of letters" (Dover 4). In other words, we would need something which informs us about Greek social interactions, their rules and dynamics. Recently, my attention has been drawn to an ambiguous passage from Aristotle's Poetics: "Sophocles claimed he made men as they should have been, while Euripides made them as they were" (1460b33-34). While it may seem difficult to draw a conclusive assessment of this statement, this claim lends a certain credibility to Euripides's depiction of the world, and scholars have hardly enquired whether it is possible to put this credibility to the test. Hence, I ask: to what extent can the thoughts, deeds, words, and reactions of Euripides's characters be said to mirror those of the Greeks of his day? The first thing to do is to determine what is "real" in Greek social life. In this respect, one cannot but recall Aristotle's description of people as "social animals" (Pol. 1253a3-4; EN 1169b18-19) who pursue reciprocal exchanges within communities. Across all ages, in order to live happily, people have always sought recognition, respect, esteem, and honor: all of these terms are meaningfully combined in the Greek word $\tau \mu \eta$, which Aristotle defines as "the greatest of external goods" and "the aim of the majority" (EN 1123b15-21, 1159a16-17). Indeed, as Øyvind Rabbås has shown, by recognizing and responding to $\tau \mu \eta$ people create a construct that has real significance for their lives.

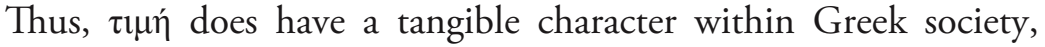
and it is a crucial (if not the crucial) mechanism by which the ancient Greeks described their social interactions and relationships: it was a right, it was an office, ${ }^{2}$ it was a reward, it was a feeling. It was, therefore, something which displayed its concreteness during reciprocal relationships. The last two decades have witnessed a rise in scholarly interest in $\tau 1 \mu \eta$ (in its varied nuances as honor, esteem, worth, dignity, etc.). Past scholarship has either (i) analysed it by means of pre-Classical comparisons (Dodds; Finley) or (ii) assessed fifth-century BCE

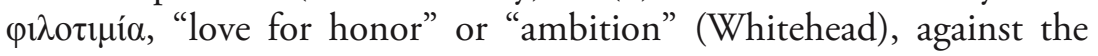
more positive accounts of fourth-century BCE sources (Dover; Liddel; Keim; Aloumpi). As a result, scholars have outlined a stark distinction between a negative notion of the pursuit of $\tau \mu \mu$ (in the fifth century $\mathrm{BCE}$ ) and a positive consideration of it (in the fourth century BCE). On the other hand, the seminal studies by Cairns on the psychological

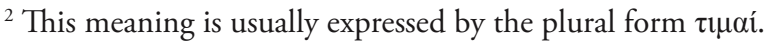


concept of $\alpha i \delta \omega$ c, "honor-shame", have assessed the active role of honor in human relationships as described in ancient Greek literature. Other scholars, such as Ruth Scodel, have re-evaluated the cohesive character of $\tau \mu \mu$ in ancient Greek epic. Also, the logic of reciprocal exchanges attested by Greek historical-epigraphic sources dealing with $\tau \mu \eta$ and

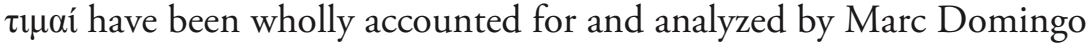
Gygax. Lastly, the Edinburgh ERC Project Honour in Classical Greece (2018-2022) claims and aims to demonstrate that Greek "honor" is a pluralist, inclusive, and flexible notion to be re-examined in light of recent findings in sociology and philosophy. This scholarly interest confirms that there is a whole "honor world" in ancient Greek society which has yet to be fully explored. In particular, there is plenty of room to reconstruct honor dynamics from an internal perspective too: instead of examining Greek society by means of recent philosophical/ sociological concepts, it is possible to identify ancient paradigms of $\tau \mu$ í within ancient contexts, through a comparative analysis of Classical epigraphic, literary and philosophical sources.

To be sure, drama has often been considered a repository of moral values and discourses (Adkins; Blundell; Cairns, AIDŌS; Belfiore). What I wish to ask here is whether Euripides's peculiar portrayal of social relationships may represent a valuable case study to examine how people realistically interact and pursue various kinds of $\tau \mu \eta \eta$, in a variety

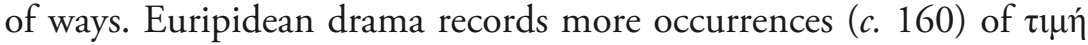
(and cognates) than Aeschylean and Sophoclean drama. Moreover, Euripides displays an impressive interest in moral issues regarding "honor" in social contexts: on the one hand, Euripides addresses ambition as a device by which to deal with unstable/dishonorable circumstances; on the other hand, he does not hesitate to point out the backlashes of the selfish pursuit of $\tau \imath \mu$, which risks turning into ü $\beta p 1 s$ (Fisher; Cairns, "Hybris, Dishonour") when each character forcefully seeks to assert his or her own rights/claims.

This twofold treatment of "honor" attests to the realistic and inevitable limits and negotiations which can occur in reciprocal relations. Indeed, while providing examples of the civic-minded pursuit of $\tau \mu \mu$ (which brings benefits both the individual and the community), Euripides's plays also betray the fifth-century BCE concern for ambitious attitudes within an egalitarian community. Hence, Euripidean drama displays a subtle interest in cases in which social dynamics lead ambition to fail. Against the resultant tragic consequences, Euripidean characters - truly acting as sociable people—react by seeking $\tau \mu$ í through reciprocal relationships rooted into virtuous attitudes, such 
as benevolence, friendship, euergetism, charity, etc. Now, the credibility of Euripides's "social world" is substantiated (both in terms of language proximity and of the contexts described) by the parallel accounts on socio-ethical behaviors in relation to $\tau \mu$ n provided by two different genres, honorific epigraphy and Aristotle' ethics. Since $\tau \mu \eta_{\text {in }}$ is the major object/subject regulating Greek social life, one can test the reality of Euripidean drama against those sources which specifically deal with honor, and look for a reliable assessment of honor both when it is sought "more and less than is right" and when it is sought "rightly" (Arist. EN 1125b19-20). This can be done by turning, on the one hand, to those accounts and records which provide multiple social guidelines about human dynamism with respect to honor, i.e. fifth-century BCE honorific epigraphy; and, on the other hand, to the only systematic sources on the individual behaviors and moral values of people operating within a community, i.e. Aristotle's Nicomachean Ethics and Eudemian Ethics, where the social dynamics of ambition are remarkably discussed. In such a way, it is possible to show that Euripides's representation of social interactions actually mirrors the same language and setting as honorific epigraphy; and that, according to Aristotle's description of tragedy as the "imitation of action and life" (Poet. 1450a16-17), Euripides's social portrayal of $\tau \mu \eta$ also complies with Aristotle's description of society, where human beings, while pursuing a honorable status, are bound together by "reciprocation", "need", and "friendship" (EN 1132b33-1155a22-23 passim). The honorific dimension of Euripidean drama can be contextualized and examined socially (through epigraphy) as well as ethically (through Aristotle).

Epigraphic sources preserve many instances of state decrees con-

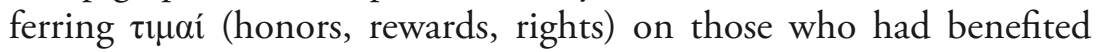
or helped the people and the city of Athens. This material provides solid evidence of the Athenian approach to beneficial (inter)actions. While praising benefactors' deeds, honorific decrees also single out "social behavior[s]" (Lambert 71), thereby characterizing the pursuit of $\tau \mu$ in on the basis of moral habits and specific virtues (such as magnanimity, courage, friendship, and benevolence). Through honorific decrees, Greek $\pi$ ó $\lambda \varepsilon 1 \varsigma$ conferred honors and awards on their benefactors, established socio-political relationships and alliances, and publicly displayed their gratitude to those who provided (usually economic) assistance. Thus, from the fifth century BCE onwards, Greek $\pi$ ó $\lambda \varepsilon 1 \varsigma$ gradually experienced a popular rush to gain honors and rewards through public benefactions. It goes without saying that the 
advantage was double, as both the benefactor and the benefited would give something while receiving something in return, based on a system of reciprocation:

\begin{abstract}
$\mathrm{X}$ benefits the city; city honors $\mathrm{X}$; because of this honor the city expects $\mathrm{X}$ to continue benefiting the city. The logic, honor based on past behavior but looking to influence future behavior, is the same as that of the hortatory intention clause. Commonly an honorific decree represents just one point along a line of mutually beneficial exchanges that extends back generations into the past and is expected to continue long into the future, an extension in time reflected in the wording of the decrees themselves: in the frequent recognition that an honorand's benefactions continue a tradition of benefaction begun by his ancestors, and in the common extension of honors to descendants. (Lambert 73)
\end{abstract}

By elucidating the moral context of these relationships, the deeds praised are defined by the ethical characterization of agent(s) and receiver(s), whose accurately delineated virtues produce laudable choices. More importantly, honorific discourse attests to an ideology shared by multiple parties, and which establishes an expectation of reciprocity feeding people's ambition. What has not yet been noted, however, is how closely the vocabulary and mechanisms of honorific practices fit the interactions represented in Euripidean drama. In Euripides's plays, characters' attitudes appear to conform to a collectivist ideology established by means of reciprocal favors and benefits aimed at the achieving of $\tau \mu \eta$ (which, within a tragic context, can entail the pursuit of fame, wealth, esteem, vengeance, marriage, or power). Euripides's plays meaningfully integrate the information provided by the epigraphical material which, insofar as it only records the result of reciprocal actions, glosses over the background motivations/evaluations of the parties involved. Thus, Euripidean interactions, that illustrate the social dynamics in which $\tau \mu$ í is embedded, also provide a meaningful way of integrating the epigraphic sources. This opens up a whole new spectrum of questions concerning the "honorific dimension" of Euripidean drama, e.g.: what social conditions determine the recognition of $\tau \mu \mu$ ? ? What motives (benefits/sacrifices) underlie the pursue of it? Combining the fixed image of $\tau \mu \mu$ preserved by the epigraphic sources with Euripides's lively depiction is an innovative way to examine human motivations/evaluations for seeking an honorable status (either as individuals or collectively).

For instance, Euripides's Medea displays a rhetoric strongly related to the concept of reciprocity (Schein). In parallel, the play provides 


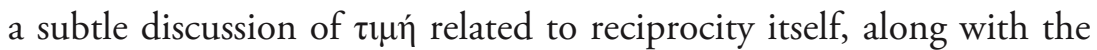
use of technical terms which we usually find in inscriptions. Indeed, Euripides's stress on Medea's lack of $\tau \imath \mu$, due to Jason's betrayal of his family and interruption of reciprocity, can be analyzed in the light of the dynamics of the Athenian honorific system by which $\tau \mu$ in was achieved through reciprocation (Giannotti, "Something"). Medea finds herself in a ruthless context, as Jason's individualistic attitude does not agree with the habit of reciprocating and of rewarding friends and benefactors. Medea has to acknowledge that Jason will not $\pi \rho \alpha \dot{\xi} \xi \varepsilon v$ $\kappa a \lambda \tilde{\omega} \varsigma$ (v. 500) towards herself-the concept of "doing good towards someone" in return for a benefit received ( $\dot{\alpha} v \tau i$ ஸ̃v $\varepsilon \tilde{v} \pi \varepsilon \pi \circ$ oí $\kappa \varepsilon v$ ) is common in honorific decrees (e.g., $O R 182, I G \mathrm{I}^{3} 125$, and $O R 191+R O$ 2). Unfortunately, even the king of Corinth, Creon, does not reward Medea for her previous help in ending Corinth's famine. Without Jason and Corinth giving Medea what she is entitled to, Medea lacks $\tau \mu \mu \eta$. Hence, this woman, $\eta \tau \imath \mu \alpha \sigma \mu \varepsilon \dot{v} \eta$ and $\alpha \ddot{\tau} \tau \mu$ s, will be redeemed only by the friendly and benevolent attitude of Aegeus, $\pi \rho \theta^{0} \theta \mu{ }^{\circ} \varsigma$ (v.

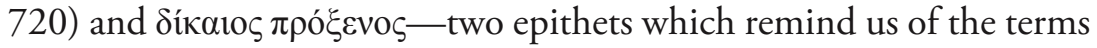
used to describe benefactors of Athens (e.g. OR 157, 184, 187). Both characters find themselves in dishonorable circumstances and seek $\tau \mu \eta$ : on the one hand, Aegeus, a man and king, is ö $\pi \alpha 1 \varsigma$ (v. 670); on the other, Medea and her children are ö $\tau$ нor (v. 696). However, there is a difference between the two characters: Aegeus is honorless in a moral sense as a king's sterility was considered shameful; Medea, as said above, is ö $\tau$. herself and her children as ö $\tau$ tuot so that her status may be rehabilitated

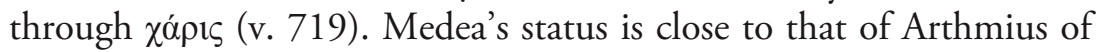

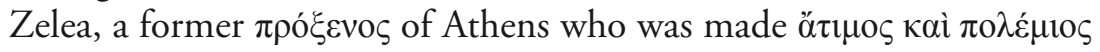

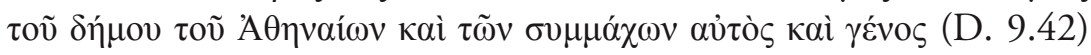
for having brought Persian gold into the Peloponnese (probably in the 470 s BCE). Both were officially banished from the land and risked being killed during their wanderings. After having been declared an enemy ( $\pi 0 \lambda \varepsilon \mu$ íos) of the Athenians, Arthmius became an enemy of Athens's allies too. Accordingly, Medea is declared "hostile" (v. 323) by Creon, who in turn has already been called an "enemy" (along with his family and Jason, v. 278) by Medea herself. Once Medea has made her intentions clear, she calls herself $\dot{\chi} \chi \theta \rho \alpha \dot{~ o f ~ t h e ~ C o r i n t h i a n ~ r o y a l ~ f a m-~}$ ily and Jason (v. 875; but cf. already v. 16). Moreover, Jason offers an

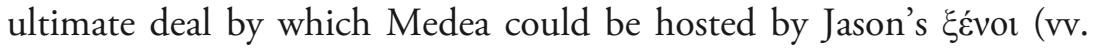
612-613), i.e. guest-friends obliged to treat him-and be treated by him—respectfully. By rejecting both Jason's and his ġ́voı's friendship, 


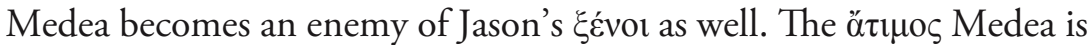
thus forced to wander as an exile and to flee Corinth, Jason and their allies as their common enemy. Epigraphy and oratory also attest to the meaning of $\dot{\alpha} \tau \mu i \dot{\alpha} \alpha$ as the deprivation of rights and properties, as is the case with: OR 131 attesting to Athenian relations with Chalcis (446/5 or $424 / 3 \mathrm{BCE}$ ); OR 142 concerning the foundation of the Athenian colony at Brea (c. 440-432 BCE); Andocides on the supporters of the Peisistratids (1.106); and Thucydides on the homecoming of the Spartan prisoners from Sphacteria (5.34.2). It is clear that Medea is

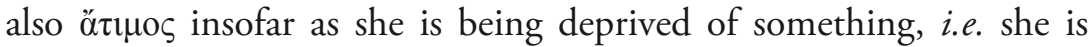
deprived of her status as a wife. Only through a reciprocal exchange will Medea get her $\tau \imath \mu$ í back: by solving the problem of Aegeus's sterility, she will return to being a married and honorable woman in magnificent Athens, as described by the Chorus (vv. 824-865). Medea

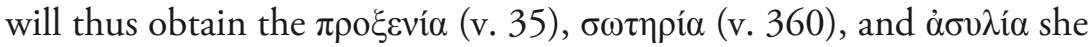
was looking for (v. 387).

A similar pattern can be identified in further Euripidean plays, where we find a proper "vocabulary of $\tau \iota \mu \eta^{\prime}$ " and honor-related concepts. We can briefly mention another example, that is, Euripides's Heracles, whose many passages reveal honorific, euergetic and reciprocal themes (Giannotti, “Heracles' Honours”): Heracles's virtues, his praise, and the rewards he receives seem to reflect the contemporary honorific, euergetic and diplomatic political system together with its rhetoric. The "honorific core" of the play is the scene involving Theseus and Heracles, which has the same structure as Medea's Aegeus episode. After Heracles has suffered the consequences of Lycus's "disrespectful" (v. 557) ambition and Hera's vengeance (through Iris and Lyssa), Theseus comes to pay him what he is rightfully due. Indeed, Heracles's status as benefactor is already clear in the first part of the tragedy: he has helped Thebes, but has not received what he deserves (vv. 264-265); having demonstrated his $\varphi \imath \lambda i \alpha$, Heracles should have receive respect (v. 301); the Thebans, despite having received benefits from Heracles, have turned out to be evil people (vv. 568-569). When we finally come to the meeting between Theseus and Heracles,

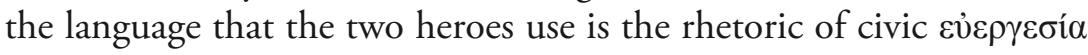
with the reciprocity it implies. Theseus, in the role of an ally, wants to return the favor Heracles has done by rescuing him from Hades (vv.

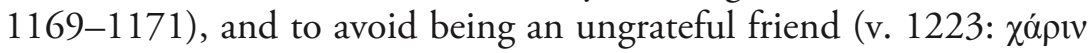

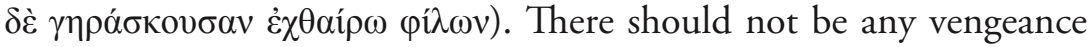
between friends, and the two heroes recognize that, in turn, one has done good and the other has benefited from it (vv. 1234-1236). After 
this rhetorical exchange, Heracles is explicitly labelled as "humanity's great benefactor and friend" and Theseus, on behalf of Athens, offers his help, seeking to make Athens the only city honoring him and to secure future benefits. Moreover, when Theseus closes his honorific speech (vv. 1322-1337) by saying "and I will repay you in this way, for having freed me" (vv. 1336-1337), he is explicitly conferring euergetic honors which, "like counter-gifts, aimed to re-establish a balance in the relationship with the benefactor and pay off the debt generated by the benefaction" (Domingo Gygax 45). Indeed, many poleis emphasized the fact that they were rewarding their benefactors in an

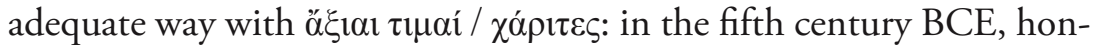
ors such as citizenship, the right to own land, freedom of entry and exit from the harbor, proedria, stelae, and statues were all designed to repay benefactors' deeds. This is what Theseus was doing-this, and more: by stating that the Athenians would be praised in the future for having helped a man like Heracles, Theseus was making a prolepsis, which is why we can speak of "proleptic honors." Indeed, "the honors awarded to provoke benefactions were, to a considerable extent, designed to surpass in due proportion the debt aroused by the gift [...] that required repayment" (Domingo Gygax 45). Theseus's gifts to Heracles were nothing but a pompous and majestic reward for his favor. But, "at the same time, because of the reciprocity mechanisms of euergetism, which led to expectations that honors would lead to benefactions, these honors were to a substantial degree experienced as a recompense for benefactions yet to come, as counter-gifts in advance or proleptic honors" (45). Again, $\tau \imath \mu \eta$ is what unites the two parties and makes them reciprocate.

Further inquiries of this kind can be conducted in relation to Euripides's Hecuba, where Priamus's wife is betrayed by Polymestor's

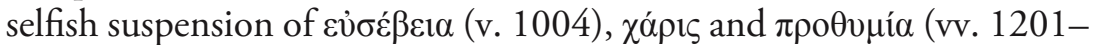
1202), and pidia (vv. 1226-1227), and the Supplices, where wise, noble, and pious Theseus helps the Argives because he knows that "the endeavour brings honor" (v. 306). All Euripidean interactions should be analyzed in the light of the concepts of reciprocation and benefaction. Euripides stages characters who, for all their depth and complexity, are not, as Dover claims, "different in scale and kind" (v. 18) from their audience. Rather, Euripidean characters' interactions often mirror the social guidelines on the basis of which Greeks used to engage with one another. Honorific epigraphy represents a reliable tool to test Euripides's theatre as a "space of sociality" (Canevaro) in which $\tau \iota \mu$ ' and people's approaches to it are at play. 
But what about a moral evaluation of Euripidean characters' choices within reciprocal relationships? In a world marked by the complex dynamics of individual and collective pursuit of $\tau 1 \mu \eta$, a viable solution to positively direct one's desire for honor and esteem is the application of certain virtues. Thus, how can $\tau$ tú be properly pursued? Any exhaustive understanding of honor dynamics should consider the first comprehensive Greek handbooks on how to act and behave in social life, namely Aristotle's ethical works (Eudemian Ethics and Nicomachean Ethics). Insofar as Aristotle's works address $\tau \mu \mu$ as a central topic and discuss the ethical implications (virtues/vices) of honor in action, they provide a systematic overview of how $\tau \iota \mu$ is evaluated and classified within the context of social interactions. In particular, Aristotle scrutinizes honor-related virtues and establishes the conditions for laudable and despicable actions. It is striking that the virtues touched upon in Aristotle's analysis are precisely those displayed by Euripidean characters and praised by honorific decrees.

Aristotle's work focuses on the theory of human actions, expounding on how these are performed, what their aim is, and what virtues should guide them (EN 1103b26-31). According to Aristotle, choice generates an action through which a certain relationship arises. Yet, it is within human relationships that people become just or unjust (EN 1103b14$15)$, and virtues, which concern behaviors in context, consequently concern "social life" (EN 1108a10-11). Since, as honorific epigraphy and Euripidean interactions also show, relationships in action make virtues

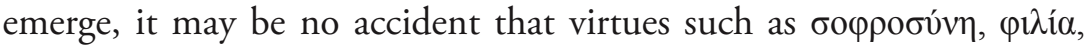

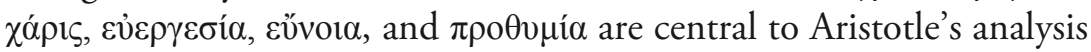
of individual as well as collective action. Indeed, Aristotle shows that only the above-mentioned moderate virtues, esp. "reciprocal benevolence" (EN 1156a3-4), create a friendly community where one can do great favors with a proportionate effort. Euripidean characters' deeds, words, and feelings can be interpreted through Aristotle's ethical lens: this would allow us, for example, to contextualize characters' virtues (courage, temperance, generosity, magnanimity, justice) and to understand how one individual's virtuous actions relate to another individual's honorable or dishonorable status (through the so-called "person parameter"). While honorific epigraphy can tell us something about who benefited whom and how, Aristotle's ethical works specifically explain "morally right action" as a matter of "who one acknowledges as entitled to be taken into account when one acts" (Rabbås 626).

The philosopher's testimony crucially provides a realistic moral discussion of Greek honor culture akin to Euripides's treatment 
of $\tau$ $\tau$. If Greek tragedy is usually read through the guidelines of Aristotle's Poetics, why cannot Euripides- he who portrayed people in a "realistic" way-be read through Aristotle's ethical guidelines? Aristotle's ethics is one of the very few areas within ancient thought which are studied not merely for their historical value, but also on account of the enduring relevance of their contents. Especially in the UK, Aristotle's ethics is being widely studied and considered as the major opponent of attempts to reduce human action to a mere natural event: for this reason, Aristotle's discussion on friendship and virtue is regarded highly. Focusing on Euripidean characters and comparing their words during social interactions to those attested by honorific epigraphy, and their actions and virtues to those described by Aristotle in his ethical portrayal of the dynamism of human society, can initiate a fruitful intradisciplinary analysis: the honor-related guiding thread underlying Euripides's plays can be envisaged as a key aspect of ancient Greek society's discussion about itself, embracing varied genres and producing an equally varied literature and narrative about its own socio-ethical structure.

By investigating how honor dynamics are described in these three different sources (ancient Greek epigraphy, literature, and philosophy), I believe that it is possible to unveil a shared set of assumptions in relation to $\tau \mu \eta$ across the fifth and fourth centuries BCE, and to outline the honor-paradigm governing the ancient Greeks' ambitions and actions. In such a way, a reliable reconstruction of the social, ethical and civic value of a cardinal concept, honor, can be provided. Through the lens of the honor code, the classic binary logic applied to characters on stage (bad/good) would be reappraised as the depiction of two (or more) contracting parties expressing and experiencing the inevitable limits and negotiations which occur in reciprocal human relations. The social setting provided by epigraphy and the ethical explanations provided by Aristotle allows us to consider the actions and behaviors of tragic characters according to a historically and ethically informed perspective. Not only that, but such a reappraisal of the socio-ethical dimension of Euripides's dramatic world offers the opportunity to reassess the educational value of ancient Greek tragedy today. In times like these, where (also due to Covid19) ethical principles risk crumbling under the weight of individualism and isolation, a positive representation of "honor" based on reciprocation, respect, and solidarity may prove instructive for the social progress of our alienated modern democracies. By providing potential frameworks for integrating the individual pursuit of $\tau \mu \eta \eta$ 
into a community, Euripides's plays may serve as a surprisingly contemporary model for reappraising honor in modern societies_-as, e.g., Appiah and Sommers have recently done by considering and comparing other pre-modern cultural products and ethical beliefs. Hence, this analysis would ultimately demonstrate the importance of Euripides's socio-ethical testimony, reasserting the relevance of his theatre in the ancient and contemporary debate on the value of honor for human societies.

\section{WORKS CITED}

Adkins, Arthur W. H. Merit and Responsibility. A Study in Greek Values. Oxford: Clarendon Press, 1960.

Aloumpi, Myrto. The Civic Virtue of Philotimia. Rhetoric, Ideology, and Politics in Democratic Athens. DPhil dissertation. Oxford: Oxford University, 2018.

Appiah, Kwame A. The Honour Code. How Moral Revolutions Happen. New York, NY; London: Norton, 2010.

Arrowsmith, William. "Nietzsche: Notes for 'We Philologists'." Arion 1.2 (1973-1974): 279-380.

Branham, Robert B., Glenn W. Most, Ralph Hexter, Giulia Sissa, Daniel Selden, Page duBois, and Walter R. Johnson. "Panel Discussion. Classics and Comparative Literature: Agenda for the '90s." Classical Philology 92.2 (1997): 153-188.

Barbato, Matteo. The Ideology of Democratic Athens. Institutions, Orators and the Mythical Past. Edinburgh: Edinburgh University Press, 2020.

Belfiore, Elizabeth S. Murder among Friends. Violation of Philia in Greek Tragedy. New York, NY; Oxford: Oxford University Press, 2000.

Blundell, Mary W. Helping Friends and Harming Enemies. A Study in Sophocles and Greek Ethics. Cambridge: Cambridge University Press, 1989.

Cairns, Douglas L. AIDŌS. The Psychology and Ethics of Honour and Shame in Ancient Greek Literature. Oxford: Clarendon Press, 1993.

Cairns, Douglas L. "Hybris, Dishonour, and Thinking Big." The Journal of Hellenic Studies 116 (1996): 1-32.

Canevaro, Mirko. "I diritti come spazio di socialità: la timè tra diritto e dovere." Dike. Ovvero della giustizia tra l'Olimpo e la terra. Eds. Alberto Camerotto and Filippomaria Pontani. Milano; Udine: Mimesis Edizioni, 2020. 157-177.

Dodds, Eric R. The Greek and the Irrational. Berkeley, CA: University of California Press, 1951.

Domingo Gygax, Marc. Benefaction and Rewards in the Ancient Greek City. The Origins of Euergetism. Cambridge: Cambridge University Press, 2016.

Dover, Kenneth J. Greek Popular Morality in the Time of Plato and Aristotle. Oxford: Blackwell, 1974.

Finley, Moses I. The World of Odysseus. New York, NY: Viking Press, 1954.

Fisher, Nick R. E. Hybris. A Study in the Values of Honour and Shame in Ancient Greece. Warminster: Aris \& Phillips, 1992.

Giannotti, Andrea. "Something to Do with Epigraphy? The Aegeus Episode in Euripides'

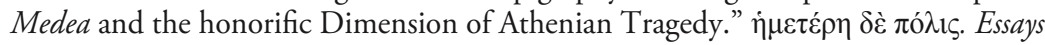


in Honour of Peter J. Rhodes on the Occasion of his 80th Birthday. Eds. Delfim Leão and Rui Morais. Oxford: Archaeopress, 2021. [forthcoming]

Giannotti, Andrea. "Heracles' Honours: The Dynamics of Greek honorific Practice on Stage." Poétique et politique. Nouvelles lectures d'Euripide. Eds. Pascale BrilletDubois, Boris Nikolsky, and Anne-Sophie Noel. Lyon: Éditions de la MOM, 2021. [forthcoming]

Keim, Benjamin. "Xenophon's Hipparchikos and the Athenian Embrace of Citizen Philotimia." Polis 35 (2018): 499-522.

Lambert, Stephen D. Inscribed Athenian Laws and Decrees in the Age of Demosthenes. Historical Essays. Leiden; Boston: Brill, 2018.

Liddel, Peter. Civic Obligations and Individual Liberty in Ancient Athens. Oxford: Oxford University Press, 2007.

Rabbås, Øyvind. "Virtue, Respect, and Morality in Aristotle." The Journal of Value Inquiry 49 (2015): 619-643.

Scodel, Ruth. Epic Facework. Self-Presentation and Social Interaction in Homer. Swansea: Classical Press of Wales, 2008.

Sommers, Tamler. Why Honor Matters. New York, NY: Basic Books, 2018.

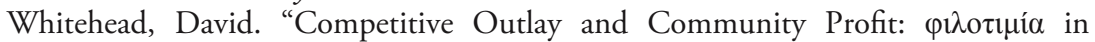
Democratic Athens." Classica et Mediaevalia 34 (1983): 55-74.

\section{Razpravljanje o časti v Atenah iz 5. stoletja pr. n. š.: primerjalni in intradisciplinarni pristop}

Ključne besede: literatura in etika / starogrška dramatika / epigrafika / Evripid / Aristotel / moralna filozofija / čast

Članek ni toliko praktični prikaz kot teoretični oris in predlog novih pristopov $\mathrm{k}$ določenemu vidiku starogrške kulture, tj. »časti« ( $\tau 1 \mu \eta ́)$. Cilj ni le ponazoriti, kako potencialno napredna je takšna metodologija (in pripraviti podlago za njeno uporabo), temveč tudi izpostaviti konkretne priložnosti v humanistiki za preučevanje načinov, na katere jezik civilnih institucij v epigrafskih virih in moralni jezik etične filozofije prodreta v grško poezijo: miselnost, da so epigrafi in etična filozofija nekaj, kar morajo strokovnjaki za poezijo prepustiti zgodovinarjem, specialistom za stari vek, in filozofom, je pustila veliko prostora za nova dognanja na tem področju. Posebna pozornost je namenjena Evripidovi dramatiki in likom, ki z izkazovanjem posebnih vrlin (npr. dobrohotnost, solidarnost, prijateljstvo) in ob vzpostavljanju recipročnih odnosov predstavljajo družbeno-etični primer uveljavljanja častnega statusa v svoji 
skupnosti. Stroka še ni raziskala, v kolikšni meri se ta upodobitev ujema z zgodovinskimi dokazi o dobrih delih in plodnih izmenjavah med grškimi državljani/mesti in koliko je v skladu z vrlinami, ki jih opisujejo Aristotelova dela o etiki. Cilj razlage časti kot sredstva, s katerim ljudje regulirajo svoje družbeno življenje, je pokazati, da je lahko evripidska drama dragocen vir za razumevanje grških moralnih stališč.

1.01 Izvirni znanstveni članek / Original scientific article UDK 821.14'02Euripides:17

DOI: https://doi.org/10.3986/pkn.v44.i2.03 